\title{
ASSESSMENT OF SUGARCANE VARIETAL DAMAGE FROM FIELD RATS AND THEIR MANAGEMENT STRATEGY IN SINDH
}

\author{
Amjad Pervez, Syed Muzaffar Ahmad and Syeda Azra Tariq \\ Vertebrate Pest Control Institute, Southern zone Agricultural Research Centre, \\ Pakistan Agricultural Research Council, Karachi University Campus, Karachi-75270 \\ E-mail: dramjadvpci57@gmail.com
}

\section{ABSTRACT}

Sugarcane crop is highly vulnerable to attack by a complex of rodent pest species due to its long duration, providing excellent protective cover for field rats to feed and thrive throughout the year. Damage survey conducted at crop maturity stage (September-November) at Palejo Farm, Thatta revealed that BL-4 variety was heavily attacked due to its softness (10.40\%) followed by BF-129 variety $(8.63 \%)$ and least affected was Thatta-10 variety $(6.62 \%)$. Rat damaged cane become further infested with other micro-organism and physical stress, resulting in reduction in weight and sugar recovery. Rodent control trials through application of PARC Rat bait formulations containing Zinc Phosphide (2\%), Bromadiolone (0.005\%) and Brodifacoum (0.005\%) alongwith additive (Egg $3 \%$ ) showed remarkable reduction in pest population. Brodifacoum mixed bait emerged as highly effective formulation showing $92.63 \%$ reduction in pest population followed by Bromadiolone bait $(89.02 \%)$ and Zinc phosphide bait (83.54\%). For effective management of field rodents, Integrated Pest Management (IPM) approach is recommended with combination of mechanical, chemical and habitat manipulation practice to enhance the crop yield through effective rat pest management.

\section{INTRODUCTION}

\section{Sugarcane}

(Saccharum officinarum) is an important cash and industrial crop and occupies a significant portion in the economy of Pakistan. Survival of sugar industry in Pakistan is totally dependent on sugarcane cultivation, because it is source of raw material to the sugar industry for the manufacturing of sugar and several other by-products. Pakistan occupies an important position in cane producing countries of the world as it ranks 5th in cane area and 15th in sugar production (FAO, 2003).

Sugarcane is a long duration crop and thus provides an ideal condition for a complex of rodent population to subsist and causes extensive damage through eating into internodes and roots. This damage becomes more prominent in lodged sugarcane. Rat damaged sugarcane becomes infested with various microorganisms and other physical stresses resulting in reduction of its weight and sugar recovery (Hampson, 1984) recorded $3.7 \%$ (range $3-4 \%$ ) mean sugar loss for every $10 \%$ damage of sugarcane. In a rat damage survey by Fulk et. al., (1980) at Fauji Sugar Mills, Khoski, Badin, $10.7 \%$ loss to sugar production was recorded, Smiet et. al., (1980) estimated $24 \%$ damage to cane in Thatta district, lower Sindh. Khan (1990) calculated economic losses of Rs. 140.6 manually based on 1986-87 production and support prices. The detail survey conducted by Vertebrate Pest Control Institute of Pakistan Agricultural Research Council, Karachi, a complex of five rodent pest species have been recorded to invade and inflict severe damage to sugarcane crop in Sindh and Punjab. Rat species include lesser bandicoot rat, Bandicota bengalensis; short-tailed mole rat, Nesokia indica; soft-furred field rat, Millardia meltada and field mouse, Mus booduga. Numerous studies have been conducted to ascertain the population complex, damage pattern and its management through incorporating traditional and poison baiting (Fulk et. al., 1980; Smiet et al 
1980; Beg and Khan, 1982; Brooks et. al., 1989; Khokhar et. al., 1995; Pervez et. al., 1999 \& 2005; Rizvi, 2004). Present study is based on nature and extent of sugarcane damage due to rodents and possible management approaches to minimize rodent pest population for adoption by the end-users.

\section{MATERIALS AND METHODS}

\section{Damage Survey:}

Damage survey to ascertain field rodent species complex was conducted at crop maturity stage (September November, 2013) at Palejo Farm, Thatta and three commercially grown varieties e.g. BL-4, BF-129 and Thatta10 were sampled at monthly basis. Snap trapping was conducted to ascertain the field rodent species complex in standing sugarcane crop.

\section{Bait application trials:}

Three rodenticidal baits e.g. Zinc phosphide bait (acute rodenticidal bait), bromadiolone bait and brodifacoum bait (Second generation anticoagulant baits) were conducted from July to November, 2013 in 50 bait station/block of each variety. Post-treatment rodent activity was monitored by placing tracking tiles at interval of $20 \mathrm{~m}$ (Khan, 2007). The efficacy of offered baits was calculated on the criteria of reduction in rodent activity, yield of harvested and counts of damaged canes.

\section{RESULTS AND DISCUSSION}

Table-1 shows overall percentage of sugarcane crop damage by different rodent species on three sugarcane varieties during July-November, 2013 grown in different blocks. Sugarcane variety BL-4 was recorded the worst affected by rats followed by BF-129 whereas, Thatta-10 was the least damaged variety by rats. Rodent control trials were conducted at various growth stages of the crop on three different varieties grown in farms viz, BL-4, BF-129 and Thatta-10. Data of Table-2 revealed that additive poison baits using mixture of wheat flour and broken rice as bait base and egg additive (3\%) along-with Zinc phosphide (2\%), an acute rodenticide and bromadiolone $(0.005 \%)$ and brodifacoum $(0.005 \%)$ being anticoagulant rodenticides were prepared and evaluated separately. Brodifacoum mixed bait was highly preferred (92.63\%) followed by bromadiolone $(89.02 \%)$ and Zinc phosphide was emerged as least preferred bait (83.54\%) against field rodents to knock down pest population. Observations on the sugar crop damage survey conducted at Palejo Farm, Thatta revealed that BL-4 emerged as heavily attacked sugarcane variety by field rodents due to its soft texture in comparison to Thatta-10 and BF-129 (Ghulabi) which are relatively hard texture and erect varieties. Three poison bait formulations containing Zinc phosphide bait, brodifacoum bait and bromadiolone baits containing egg as additives were tested in separate blocks in pellet formulation. All baits were placed in protective bait stations for safety of nontarget species of birds and other mammals. Egg mixed brodifacoum proved the most promising one in achieving $92.63 \%$ rat mortality followed by bromadiolone bait (89.02\%) and Zinc phosphide bait (83.54\%). These finding are in agreement with field trials conducted in paddy and wheat (Pervez et. al., 1999 \& 2005). Similar poison baiting trials were conducted in sugarcane crop against existing rodent population by Hampson (1984) have clearly resulted in complete control of existing rodent pest population and reduction in damage to crop. The effectiveness of the bait offered is affected by number of ecological factors in field situation such as rodent species composition, postcontrol re-infestation, stage of crop development, climatic factors, crop harvesting time, sugar contents in cane and intercropping heterogeneity (Parshad et. al., 1986; Shafi et. al., 1992; Buckle and Smith, 1994). The application of formulated bait of various rodenticides in sugarcane crops showed promising results. Similar results were obtained by Khan (2007) during poison baiting evaluation trials in sugarcane fields in Thatta, Sindh. 


\section{RECOMMENDATIONS}

PARC Rat Bait has proved very successful in control of a complex of rodent pest population in sugarcane crop and recommended to sugarcane growers for safe, economical and easy rodent control. Farmer's participation through arranging farmer's field days, on field demonstrations and multidisciplinary approaches are recommended to knock down rats pest population, thus to enhance the crop yield. To achieve long term benefits of rodent pest problems, participation of all stake holders of the area is essential including growers, mill management and $R$ \& $D$ personnel.

Table-1 Damage by rats to different sugarcane varieties at district Thatta

\begin{tabular}{|l|l|l|l|l|}
\hline \multirow{2}{*}{ Variety } & \multicolumn{4}{|c|}{ Mean Damage (\%) } \\
\cline { 2 - 5 } & Jul-Aug & Sept-Oct & November & Overall \\
\hline Thatta-10 & 5.75 & 6.26 & 7.85 & 6.62 \\
\hline BL-4 & 9.32 & 9.95 & 11.92 & 10.40 \\
\hline BF-129 & 6.91 & 7.95 & 10.98 & 8.63 \\
\hline
\end{tabular}

Table-2 Reduction in rodent population in sugarcane crop after three different bait formulations

\begin{tabular}{|l|l|l|l|}
\hline Treatment & $\begin{array}{l}\text { Pre-Treatment } \\
\text { Activity }\end{array}$ & $\begin{array}{l}\text { Post-Treatment } \\
\text { Activity }\end{array}$ & $\begin{array}{l}\text { Reduction in } \\
\text { Rodent Activity (\%) }\end{array}$ \\
\hline Brodifacoum (0.005\%) with egg additive & 95 & 7 & 92.63 \\
\hline Bromadiolone (0.005\%) with egg additive & 82 & 9 & 89.02 \\
\hline Zinc Phosphide (2.000\%) with egg additive & 79 & 13 & 83.54 \\
\hline
\end{tabular}

\section{REFERENCES}

Beg, M. A. and A. A. Khan, 1982. The wild boar in Pakistan: Distribution, habitat and movement patterns. J. Agric. Sci. Pak. 4 (1-2): 46-51.

Brooks, J. E., E. Ahmad, I. Hussain, and M. H. Khan, 1989. The agricultural importance of the wild boar (Sus scrofa) in Pakistan. Trop. Pest Managnt. 35 (3): 128-131.

Buckle, A. P. and R. H. Smith, 1994. Rodent pests and their control. CAB International, Walling ford, UK. 405 pp.

Food and Agriculture Organization (FAO) 2003. Production year book, Rome, Italy.

Fulk, G. W., S. A. Salam, and M. T. Akhtar, 1980. Rat damage to sugarcane in Pakistan. Pakistan J. Agri. Res. 1 (2): 131-134.

Hampson, S. J. 1984. A review of rodent damage to sugarcane with criteria for the use of rodenticides. 1-18, In Proc. Conf. Org and Prac. Vert. Pest Control, Hampshire, UK.

Khokhar, A. R. 1995. Extension-oriented control trials against wild pig. Damaging agricultural crops in Punjab. Technical report No. 1. PEP/VPCL/TARI/PARC. pp. 14. 
Parshad, V. R., N. Ahmad, and G. Chopra, 1986. Effect of ecological factors on the performance of rodenticides in sugarcane. Proc. Anim. Sci. 95 (6): 726-737.

Pervez, A., S. M. Ahmad, S. Ahmad, and S. W. A. Rizvi, 1999. The significance of additive to enhance poison bait acceptance against rodents damaging paddy in lower Sindh, Pakistan. Pak. J. Zool. 37(3): 207-210.

Pervez, A., S. M. Ahmad, S. Ahmad, and S. W. A. Rizvi, 2005. Comparative field efficiency of some additive formulated baits against rodent pests of wheat crop in Sindh, Pakistan. Pak. J. Zool. 37(4): 269-274.

Rizvi, S. W. A. 2004. Extension-oriented wild boar control trials in Taluka Tando Allahyar, district Hyderabad, Sindh. J. Nat. Hist. Wild 3 (1): 23-27.

Shafi, M. M. 1994. A review of bait enhancement studies against commensal and field rodents of economic importance in Pakistan. Proc. Plant Protection Conf., Malaysia, 24-26 March, 1994.

Smiet, A. C., G. W. Fulk, and S. B. Lathiya, 1980. Rodent ecology in sugarcane in lower Sindh,

Pakistan. Acta Theiol. 25(8): 81-97. 